\title{
QUANDO A RAZÃO SE IMIPÕE, A BARBÁRIE É O CAMINHO
}

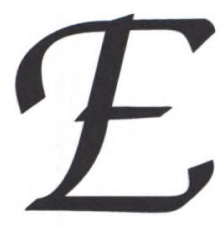

ntre os textos que se encontravam sobre a mesa de reuniões da Comissão Editorial da revista Travessia, reunida no dia 30 de setembro passado para selecionar os que seriam publicados neste número, encontrava-se uma Carta Aberta. Era de Dom Frei Luiz Flávio Cappio, bispo da diocese de Barras, na Bahia, que havia iniciado uma greve de fome em protesto contra a transposição das águas do Rio São Francisco, reivindicando a revitalização do mesmo. $\mathrm{O}$ fato teve grande repercussão no meio religioso, político e entre os movimentos sociais. Os presentes à reunião, sensibilizados pelo gesto decidido, imediatamente expressaram a sua solidariedade.

Entre os comentários tecidos, chamou particular atenção a frase final da Carta Aberta em que o bispo afirmava: Quando a razão se extingue, a loucura éo caminho, pois os textos apresentados à revista, problematizando as implicações psicológicas para a vida dos migrantes, faziam lembrar uma outra asserção: Quando a razão se impõe, a barbárie éo caminho. Sabemos da história moderna, que se orientou pelo ideário do Iluminismo, que a razão é sangrenta. "Esclarecimento" e a violência física e psíquica andaram, e andam ainda, lado a lado: a imposição do mundo moderno é um caminho de uma racionalidade destrutiva. A guerra cotidiana não poupa nem a natureza nem os seres humanos.

Eis, ainda, que entre a reunião do Conselho Editorial e a produção gráfica da revista - Dom Luiz já havia interrompido o seu jejum - sugiram os atos de violência desmesurada, resultado de frustrações acumuladas, nos subúrbios dos migrantes em Paris, que logo se espalharam pela França e algumas outras localidades da Europa.

A mobilização geral do trabalho, o deslocamento volumoso de migrantes pelo mundo globalizado, é parte integrante da racionalidade moderna e da trilha para a barbárie. Sabemos que a violência, aberta, mascarada e de múltiplas facetas contra os migrantes faz parte de uma coerção silenciosa das relações econômicas. Porém, em geral, as implicações psicológicas numa sociedade doente correm o risco de serem consideradas apenas como danos colaterais. Afinal, estamos vivendo numa "sociedade de risco" nas palavras dos sociólogos pós-modernos. O indivíduo deve saber lidar com o problema.

Todavia, se "para entender o que se passa com o indivíduo precisamos entender o contexto", devemos alertar que no contexto encontramos a dissolução de estruturas sociais e relações vitais.

A compreensão da insegurança, das incertezas, das dificuldades de integração (em que?), dos sofrimentos, das pertenças múltiplas, das desilusões, que levam à depressão e à psicose, não passa por um culto à diferença. As identidades fracionadas, percebidas apenas como fenômenos a serem encaminhados para um "multiculturalismo", experimentam no cotidiano os interesses particulares da concorrência e competição. A essência precisa "aparecer", o que não deve levar a hipostasiar a realidade social. As diferenças não podem ser nem absolutizadas nem negadas, mas devem ser vistas numa totalidade social, desde já fragmentada, segregada e estilhaçada.

Por trás dos textos apresentados no $\mathrm{N}^{\circ} 53$ da revista TRAVESSIA há uma pergunta: Que sistema social fundamenta a "hibridização" e os traumas dos migrantes mobilizados no mundo do colapso da modernização? Uma resposta séria a esta indagação ajuda-nos a fugir de uma culturalização do social, que dominou frequentemente análises sociais na última década. Nunca é tarde afirmar que as "calamidades da alma", as psicoses dos migrantes integram o lado obscuro da valorização do valor, do processo dinâmico e histórico da nossa sociedade moderna. Algo está acontecendo por trás, "nas costas" dos sujeitos individualizados. E a identidade dos sujeitos flexibilizados não consegue se opor às tendências de barbárie.

Afinal de contas, o migrante não realiza apenas como "estrangeiro" uma experiência do viajante aprendiz - o encontro entre os diferentes - ele vivencia, antes, a experiência da desigualdade e das disparidades sociais.

Heinz Dieter Heidemann 